Article

\title{
Phenolic Compounds from the Leaves of Castanopsis fargesii
}

\author{
Yong-Lin Huang ${ }^{1, *}$, Ya-Feng Wang ${ }^{1}$, Jin-Lei Liu ${ }^{1}$, Lei Wang ${ }^{1}$, Takashi Tanaka ${ }^{2}$, \\ Yue-Yuan Chen ${ }^{1}$, Feng-Lai Lu ${ }^{1}$ and Dian-Peng Li $^{1}$ \\ 1 Guangxi Key Laboratory of Functional Phytochemicals Research and Utilization, \\ Guangxi Institute of Botany, Guangxi Zhuang Autonomous Region and Chinese Academy of Sciences, \\ Guilin 541006, China; wyf@gxib.cn (Y.-F.W.); lj1@gxib.cn (J.-L.L.); jgswl@gxib.cn (L.W.); \\ chyy@gxib.cn (Y.-Y.C.); lufenglai@gxib.cn (F.-L.L.); ldp@gxib.cn (D.-P.L.) \\ 2 Department of Natural Product Chemistry, Graduate School of Biomedical Sciences, \\ Nagasaki University, 1-14 Bunkyo-machi, Nagasaki 852-8521, Japan; t-tanaka@nagasaki-u.ac.jp \\ * Correspondence: hyl@gxib.cn; Tel.: +86-773-355-0829; Fax: +86-773-355-0067 \\ Academic Editor: Derek J. McPhee \\ Received: 6 October 2016; Accepted: 13 January 2017; Published: 19 January 2017
}

\begin{abstract}
In the course of a phytochemical and chemotaxonomical investigation of Castanopsis species (Fagaceae), three new phenolic compounds, $\left(3 R, 1^{\prime} S\right)-\left[1^{\prime}-\left(6^{\prime \prime}\right.\right.$-O-galloyl- $\beta$-D-gluco-pyranosyl)oxyethyl]3-hydroxy-dihydrofuran-2(3H)-one (1), (2R,3S)-2-[2'-(galloyl)oxyethyl]-dihydroxybutanoic acid (2), and (3S,4S)-3-hydroxymethyl-3,4-dihydro-5,6,7-trihydroxy-4-(4'-hydroxy-3'-methoxyphenyl)-1H-[2]benzopyran-1-one (3) were isolated from the fresh leaves of Castanopsis fargesii. In addition, a known phenolic glycoside, gentisic acid 5-O- $\alpha$-L-rhamnopyranosyl- $(1 \rightarrow 2)-\beta$-D-glucopyranoside $(4)$ was also isolated and identified. Their structures were elucidated by means of spectroscopic methods including one- and two-dimensional NMR techniques.
\end{abstract}

Keywords: Castanopsis fargesii; Castanopsis; phenolic; cytotoxicity

\section{Introduction}

The genus Castanopsis belongs to the Fagaceae family and is commonly found in the evergreen forests of East Asia. There are about 120 species of Castanopsis, however, the classical plant taxonomy of the species is very complicated and sometimes confusing [1], thus, the application of other auxiliary methods and technologies, such as chemotaxonomy and cytotaxonomy, is necessary to identify species within this genus [2]. Previous phytochemical investigations on the plants of this genus C. fissa, C. cuspidata var. seiboldii, and C. hystrix have led to the isolation of triterpene hexahydroxydiphenoyl (HHDP) esters, HHDP glucoses, galloyl, acylated quinic acids, phenol glucosides, condensed tannins, and flavonol glycosides [3-8].

In this study, we investigated C. fargesii, which is widely distributed in southern China, where it is usually used as a traditional medicine for the treatment of diarrhea, hemorrhage, and chronic ulcers [1]. Our preliminary analysis by HPLC and TLC indicated that the leaves are rich in tannins. Subsequent chromatographic separation of the extract yielded two metabolites $\mathbf{1}$ and 2, which were identified as 2,3-dihydroxy-2-(2-hydroxyethyl)-butanoic acid derivatives, and two phenolic compounds 3 and 4. This paper reports the isolation and structural characterization of the new compounds 1-3 and an assessment of the cytotoxicity of these molecules.

\section{Results and Discussion}

The fresh leaves of $C$. fargesii were extracted with $80 \%$ aqueous ethanol, and the extract was partitioned between $\mathrm{Et}_{2} \mathrm{O}$ and water. The $\mathrm{Et}_{2} \mathrm{O}$ and aqueous fractions were separated by a combination 
of Sephadex LH-20, MCI gel CHP 20P, Toyopearl Butyl-650C, Chromatorex ODS, and Diaion HP20SS column chromatography and semi-preparative reverse-phase HPLC, to yield three new compounds 1-3 and one known phenolic compound gentisic acid 5-O- $\alpha$-L-rhamnopyranosyl-( $1 \rightarrow 2)-\beta$-D-glucoside [9] (4) (Figure 1).

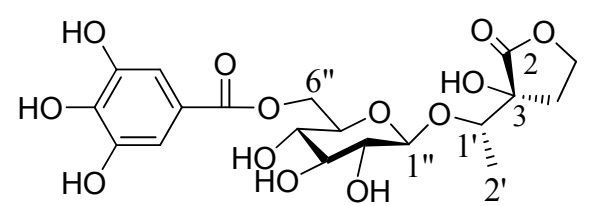

1

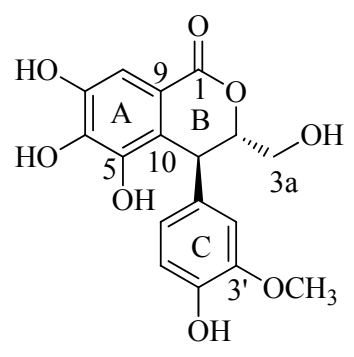

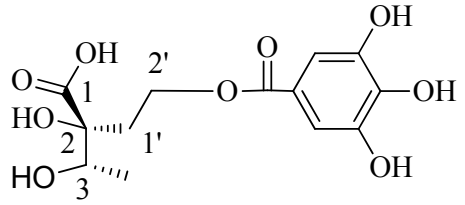

2

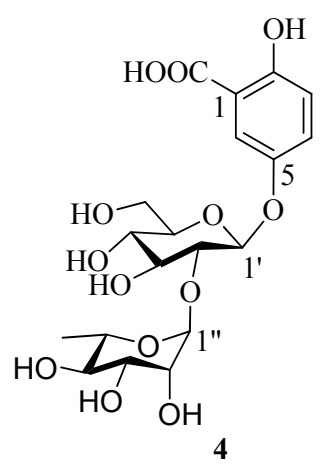

Figure 1. Structures of compounds 1-4.

Compound 1 was isolated as a brown amorphous powder and gave a positive $\mathrm{FeCl}_{3}$ test (dark blue), which suggested the presence of phenol moieties in the molecule. The molecular formula $\mathrm{C}_{19} \mathrm{H}_{24} \mathrm{O}_{13}$ was determined based on the liquid chromatography-mass spectrometry IT-TOF (LC-MS/IT-TOF), which showed $[\mathrm{M}-\mathrm{H}]^{-}$and $[\mathrm{M}+\mathrm{Na}]^{+}$ion peaks at $m / z 459.1143$ (calcd. for $\mathrm{C}_{19} \mathrm{H}_{23} \mathrm{O}_{13}, 459.1144$ ) and 483.1118 (calcd. for $\mathrm{C}_{19} \mathrm{H}_{24} \mathrm{O}_{13} \mathrm{Na}, 483.1109$ ), respectively. In the ${ }^{1} \mathrm{H}$ - and ${ }^{13} \mathrm{C}-\mathrm{NMR}$ spectra (Table 1), two proton singlets at $\delta_{\mathrm{H}} 7.13(2 \mathrm{H}, \mathrm{s})$ and four aromatic carbon signals at $\delta_{\mathrm{C}} 109.1$ and 145.2 , along with an ester carbonyl signal at $\delta_{C} 166.4$ suggested the presence of a galloyl group [10]. The hydrolysis of $\mathbf{1}$ produced D-glucose, which was identified by GC analysis. The coupling constant of the anomeric sugar proton was $7.8 \mathrm{~Hz}$, indicating that the sugar moiety was in the $\beta$ configuration. The large downfield shift of the glucose $\mathrm{H}-6^{\prime \prime}$ protons $\left(\delta_{\mathrm{H}} 4.32\right.$ and 4.58) suggested esterification with the galloyl moiety at this position. This was confirmed by the HMBC correlation between $\mathrm{H}-6^{\prime \prime}$ and the carboxy carbon $\left(\delta_{\mathrm{C}}\right.$ 166.4) (Figure 2). A second HMBC correlation between H- ${ }^{\prime \prime}$ and $C-1^{\prime}$ suggested that the glycosyl group is linked to $C-1^{\prime}$. HSQC experiment showed that the remaining moiety was composed of six carbons: a carboxy carbon $\left(\delta_{C} 178.6, C-2\right)$, an oxygenated methine $\left(\delta_{C} 77.8, C-1^{\prime}\right)$, an oxygenated quaternary carbon $\left(\delta_{C} 76.6, C-3\right)$, an oxygenated methylene $\left(\delta_{C} 65.8, C-5\right)$, a methylene $\left(\delta_{C} 29.9, C-4\right)$, and a methyl $\left(\delta_{C} 15.6, C-2^{\prime}\right)$ carbon. The presence of a $\gamma$-lactone structure in the remaining moiety was suggested by the lower field shift of the carboxy carbon $\left(\delta_{C} 178.6\right)$ and the unsaturation index (eight). This was also confirmed by HMBC correlations shown in Figure 2, in which the oxygenated methylene protons $\left(\delta_{\mathrm{H}} 4.31-4.34, \mathrm{H}-5\right)$ correlated with C-2. Furthermore, the ${ }^{1} \mathrm{H}-{ }^{1} \mathrm{H}$ COSY correlations of $\mathrm{H}-4\left(\delta_{\mathrm{H}} 2.10\right)$ with $\mathrm{H}-5\left(\delta_{\mathrm{H}} 4.32\right)$ and $\mathrm{H}-1^{\prime}$ with $\mathrm{H}-2^{\prime}$ and the HMBC correlations of $\mathrm{H}-1^{\prime}$ with $\mathrm{C}-3$ and $\mathrm{C}-4$ and $\mathrm{H}-4$ with $\mathrm{C}-2, \mathrm{C}-3$, and C-5 indicated that the remaining moiety is 3-hydroxy-3-(1'-hydroxyethyl)dihydrofuran-2(3H)-one. Consequently,

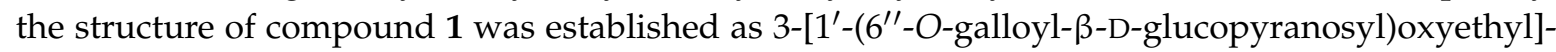
3-hydroxy-dihydrofuran-2(3H)-one.

Compound 2 was isolated as a yellow amorphous powder and gave a positive $\mathrm{FeCl}_{3}$ test (dark blue). The presence of a galloyl group was deduced from the ${ }^{13} \mathrm{C}-\mathrm{NMR}$ signals (Table 1) [6]. The molecular formula of $\mathrm{C}_{13} \mathrm{H}_{16} \mathrm{O}_{9}$ was established based on the LC-MS/IT-TOF $(m / z 339.0672$ 
$[\mathrm{M}+\mathrm{Na}]^{+}$, calcd. for $\left.\mathrm{C}_{13} \mathrm{H}_{16} \mathrm{O}_{9} \mathrm{Na}, 339.0687\right)$ and ${ }^{13} \mathrm{C}-\mathrm{NMR}$ data. The ${ }^{13} \mathrm{C}-\mathrm{NMR}$ and DEPT spectra showed signals attributable to a methyl $\left(\delta_{C} 16.9\right)$, a methylene $\left(\delta_{C} 34.2\right)$, an oxymethine $\left(\delta_{C} 71.4\right)$, an oxymethylene $\left(\delta_{C} 60.2\right)$, an oxy quaternary $\left(\delta_{C} 77.7\right)$, and a carboxyl $\left(\delta_{C} 175.4\right)$ carbons. The NMR data of $\mathbf{2}$ (Table 1) were similar to those of $\mathbf{1}$, except for the absence of the signals for one glucosyl moiety, which was supported by its MS data. A 2,3-dihydroxy-2-(2'-oxyethyl)-butanoic acid moiety could be constructed by ${ }^{1} \mathrm{H}_{-}{ }^{1} \mathrm{H}$ COSY correlations (Figure 2) of $\mathrm{H}-4$ with $\mathrm{H}-3$ and $\mathrm{H}-1^{\prime}$ a with $\mathrm{H}-2^{\prime} \mathrm{a}$ and the HMBC correlations of $\mathrm{H}-4$ with $\mathrm{C}-3\left(\delta_{\mathrm{C}} 71.4\right), \mathrm{H}-3$ with $\mathrm{C}-1, \mathrm{H}-1^{\prime}$ with $\mathrm{C}-1$, and $\mathrm{H}-2^{\prime}$ with C-2 (Figure 2). The HMBC correlation of $\mathrm{H}-2^{\prime}$ with the carboxy carbon $\left(\delta_{\mathrm{C}} 165.9\right)$ indicated that the galloyl group was attached to C-2'. Based on these results, the structure of $\mathbf{2}$ was determined to be 2-[2'-(galloyl)-oxyethyl]-2,3-dihydroxybutanoic acid.

Table 1. ${ }^{1} \mathrm{H}(500 \mathrm{MHz})$ and ${ }^{13} \mathrm{C}(125 \mathrm{MHz})$ NMR data of compounds $\mathbf{1}$ and 2 in acetone- $d_{6}$.

\begin{tabular}{|c|c|c|c|c|}
\hline \multirow{2}{*}{ Positions } & \multicolumn{2}{|l|}{1} & \multicolumn{2}{|l|}{2} \\
\hline & ${ }^{1} \mathbf{H}$ & ${ }^{13} \mathrm{C}$ & ${ }^{1} \mathbf{H}$ & ${ }^{13} \mathrm{C}$ \\
\hline 1 & & & & 175.4 \\
\hline 2 & & 178.6 & & 77.7 \\
\hline 3 & & 76.6 & $3.88(1 \mathrm{H}, \mathrm{q}, J=6.5 \mathrm{~Hz})$ & 71.4 \\
\hline \multirow[t]{2}{*}{4} & $2.10(1 \mathrm{H}, \mathrm{m})$ & 29.9 & $1.19(3 \mathrm{H}, \mathrm{d}, J=6.4 \mathrm{~Hz})$ & 16.9 \\
\hline & $2.58(1 \mathrm{H}, \mathrm{m})$ & & & \\
\hline 5 & $4.31-4.34(2 \mathrm{H}, \mathrm{m})$ & 65.8 & & \\
\hline $1^{\prime}$ & $4.01(1 \mathrm{H}, \mathrm{d}, J=6.4 \mathrm{~Hz})$ & 77.8 & $2.31(1 \mathrm{H}, \mathrm{m}), 2.36(1 \mathrm{H}, \mathrm{m})$ & 34.2 \\
\hline $2^{\prime}$ & $1.26(1 \mathrm{H}, \mathrm{d}, J=6.4 \mathrm{~Hz})$ & 15.6 & $4.31(1 \mathrm{H}, \mathrm{m}), 4.33(1 \mathrm{H}, \mathrm{m})$ & 60.2 \\
\hline $1 "$ & $4.41(1 \mathrm{H}, \mathrm{d}, J=7.8 \mathrm{~Hz})$ & 104.1 & & \\
\hline $2^{\prime \prime}$ & $3.19(1 \mathrm{H}, \mathrm{dd}, J=7.8,8.9 \mathrm{~Hz})$ & 73.8 & & \\
\hline $3^{\prime \prime}$ & $3.43(1 \mathrm{H}, \mathrm{t}, J=8.9 \mathrm{~Hz})$ & 76.4 & & \\
\hline $4^{\prime \prime}$ & $3.46(1 \mathrm{H}, \mathrm{t}, J=8.9 \mathrm{~Hz})$ & 70.4 & & \\
\hline $5^{\prime \prime}$ & $3.62(1 \mathrm{H}, \mathrm{m})$ & 73.9 & & \\
\hline $6 "$ & $\begin{array}{c}4.32(1 \mathrm{H}, \mathrm{m}) \\
4.58(1 \mathrm{H}, \mathrm{dd}, J=2.1,11.8 \mathrm{~Hz})\end{array}$ & 63.8 & & \\
\hline \multicolumn{5}{|l|}{ Galloyl } \\
\hline 1 & & 120.6 & & 121.0 \\
\hline 2,6 & $7.13(2 \mathrm{H}, \mathrm{s})$ & 109.1 & $7.10(2 \mathrm{H}, \mathrm{s})$ & 109.1 \\
\hline 3,5 & & 145.2 & & 145.0 \\
\hline 4 & & 138.1 & & 137.7 \\
\hline 7 & & 166.4 & & 165.9 \\
\hline
\end{tabular}

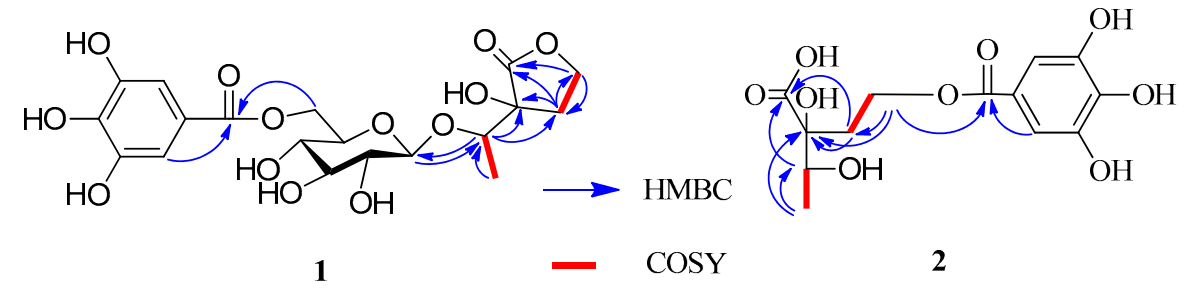

Figure 2. Key HMBC and ${ }^{1} \mathrm{H}_{-}{ }^{1} \mathrm{H}$ COSY correlations of $\mathbf{1}$ and 2.

The absolute configurations at C-2 and C-3 of 2 were established using the modified Mosher's method [11,12]. Treatment of 2 with $\mathrm{CH}_{3} \mathrm{I}$, then with $(R)-(-)$ - and (S)-(+)-2-methoxy-2-trifluoromethyl2-phenylacetyl (MTPA) chloride to get the C-3 $(S)$ - and (R)-MTPA ester derivatives, respectively. $\Delta \delta$ values obtained from the ${ }^{1} \mathrm{H}$-NMR data of the C-3 $(R)$ - and (S)-MTPA ester derivative indicated that the absolute configuration at $C-3$ of $\mathbf{2}$ was $S$ (Figure 3). Compound $\mathbf{2}$ reacted with 2,2-dimethoxypropane (DMP) and pyridinium $p$-toluene sulfonate (PPTS) to form the 2,3-O-isopropylidene derivative. The C-2 and $\mathrm{C}-3$ relative configuration of 2,3-O-isopropylidene derivative was determined based on the NOE correlation of $\mathrm{H}_{-1} \mathbf{1}^{\prime}$ with $\mathrm{H}_{3}-4$ (Figure 4). Thus, the absolute configurations at $\mathrm{C}-2$ and $\mathrm{C}-3$ of 2 were assigned as $R$ and $S$, respectively. 


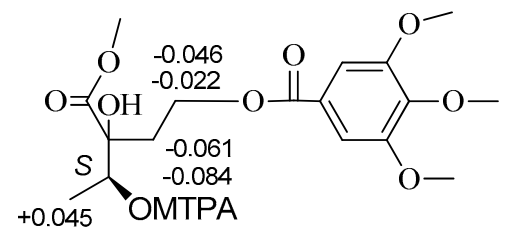

Figure 3. $\Delta \delta_{\left(S^{-} R\right)}$ values of MTPA ester derivative of 2.

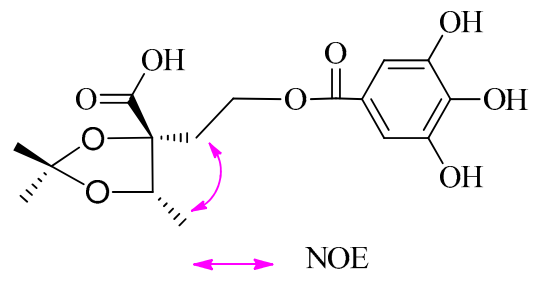

Figure 4. Key NOE correlations of 2,3-O-isopropylidene derivative of 2.

Compounds 1 and 2 both contain a 2,3-dihydroxy-2-(2-hydroxyethyl)-butanoic acid moiety. The hydrolysis of $\mathbf{1}$ in $1 \mathrm{M} \mathrm{HCl}$ yielded 3-hydroxy-3-(1-hydroxyethyl)dihydrofuran-2(3H)-one that was identified to have the same absolute configuration as 2 by comparing their $[\alpha]_{D}^{25}$ and CD data. Hence, the absolute configurations of $\mathbf{1}$ were assigned as $3 R, 1^{\prime} S$.

Compound 3 was obtained as a brown amorphous powder, which gave a dark blue color with $\mathrm{FeCl}_{3}$. The molecular formula $\mathrm{C}_{17} \mathrm{H}_{16} \mathrm{O}_{8}$ was deduced from the $[\mathrm{M}-\mathrm{H}]^{-}$peak at $m / z 347.0768$ in the LC-MS/IT-TOF (calcd. for $\mathrm{C}_{17} \mathrm{H}_{15} \mathrm{O}_{8}, 347.0772$ ). Comparison of the ${ }^{1} \mathrm{H}$ - and ${ }^{13} \mathrm{C}-\mathrm{NMR}$ data of 3 (Table 2$)$ and (3S,4S)-3-[( $\beta$-D-glucopyranosyl)oxymethyl]-3,4-dihydro-5,6,7-trihydroxy-4-(4'-hydroxy$3^{\prime}$-methoxyphenyl)-1H-[2]-benzopyran-1-one [13] revealed that the methyl at C-3 in the known compound was replaced by a hydroxymethyl in 3 . This was confirmed by the MS data and the correlations of the methine proton $\left(\delta_{\mathrm{H}} 4.67\right)$ with the methylene carbon $\left(\delta_{\mathrm{C}} 62.4\right)$ in the HMBC spectrum (Figure 5), as well as ${ }^{1} \mathrm{H}-{ }^{1} \mathrm{H}$ COSY correlations of $\mathrm{H}-3\left(\delta_{\mathrm{H}} 4.67\right)$ with $\mathrm{H}-3 \mathrm{a}\left(\delta_{\mathrm{H}} 3.54\right)$ and $\mathrm{H}-4\left(\delta_{\mathrm{H}} 4.50\right)$ (Figure 5). Comparison of the $\mathrm{CD}$ and the optical rotation $\left([\alpha]_{D}^{25}+18.3^{\circ}\right)$ data of 3 with those of similar compounds suggested that the absolute configuration is $3 S, 4 S$ [14]. Based on the above evidences, the structure of compound 3 was concluded to be $(3 S, 4 S)-3$-hydroxymethyl3,4-dihydro-5,6,7-trihydroxy-4-(4'-hydroxy-3'-methoxyphenyl)-1H-[2]-benzopyran-1-one.

Table 2. ${ }^{1} \mathrm{H}-\mathrm{NMR}(500 \mathrm{MHz})$ and ${ }^{13} \mathrm{C}-\mathrm{NMR}(125 \mathrm{MHz})$ data of compound 3 in DMSO- $d_{6}$.

\begin{tabular}{ccc}
\hline Positions & ${ }^{\mathbf{1}} \mathbf{H}$ & ${ }^{13} \mathbf{C}$ \\
\hline 1 & & 164.6 \\
2 & $4.67(1 \mathrm{H}, \mathrm{td}, J=1.1,6.5 \mathrm{~Hz})$ & 84.7 \\
3 & $3.54(1 \mathrm{H}, \mathrm{dd}, J=7.6,11.2 \mathrm{~Hz})$ & 62.4 \\
$3 \mathrm{a}$ & $3.68(1 \mathrm{H}, \mathrm{dd}, J=6.5,11.2 \mathrm{~Hz})$ & 36.7 \\
4 & $4.50(1 \mathrm{H}, \mathrm{br} \mathrm{s})$ & 144.7 \\
5 & & 139.7 \\
6 & & 145.3 \\
7 & $7.15(1 \mathrm{H}, \mathrm{s})$ & 107.7 \\
8 & & 115.3 \\
9 & & 119.9 \\
10 & & 133.5 \\
$1^{\prime}$ & & 111.8 \\
$2^{\prime}$ & & 147.6 \\
$3^{\prime}$ & & 144.8 \\
$4^{\prime}$ & & 114.9 \\
$5^{\prime}$ & $6.67(1 \mathrm{H}, \mathrm{d}, J=8.1 \mathrm{~Hz})$ & 119.6 \\
$6^{\prime}$ & $6.64(1 \mathrm{H}, \mathrm{d}, J=2.1,8.1 \mathrm{~Hz})$ & 55.4 \\
$\mathrm{OCH}_{3}$ & $3.72(3 \mathrm{H}, \mathrm{s})$ & \\
\hline
\end{tabular}




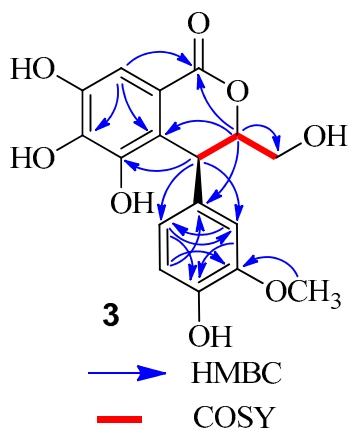

Figure 5. Key HMBC and COSY correlations of 3.

All isolates were subjected to a cytotoxicity assay in vitro against human lung epithelial A549, human hepatocellular carcinoma SMMC-7721 cell, human gastric carcinoma MGC-803 cell, liver hepatocellular HepG2 cell, and human breast adenocarcinoma MCF-7 tumour cell. Unfortunately, none of the isolates showed inhibitions of those tumour cells at the highest concentration tested $\left(\mathrm{IC}_{50}\right.$ value $\left.>10 \mu \mathrm{M}\right)$.

\section{Experimental Section}

\subsection{Materials}

The leaves of C. fargesii were collected at Guangxi Institute of Botany, Guangxi, China, in August 2014, and were identified by Prof. Shi-Hong Lu. A voucher specimen (20140627) was deposited in the Guangxi Key Laboratory of Functional Phytochemicals Research and Utilization, Guangxi Institute of Botany, China.

\subsection{General Experimental Procedures}

Optical rotations were measured with a 341 digital polarimeter (Perkin-Elmer Corp., Waltham, MA, USA). ${ }^{1} \mathrm{H}$ - and ${ }^{13} \mathrm{C}$-NMR spectra were measured in acetone at $27{ }^{\circ} \mathrm{C}$, using an Avance 500 spectrometer (500 MHz for ${ }^{1} \mathrm{H}$ and $125 \mathrm{MHz}$ for ${ }^{13} \mathrm{C}$, Bruker Biospin AG, Fällanden, Switzerland). Coupling constants and chemical shifts were given in $\mathrm{Hz}$ and on a $\delta$ (ppm) scale, respectively. GC was performed on a $6890 \mathrm{~N}$ instrument equipped with a FID detector (Agilent Technologies, Santa Clara, CA, USA) operated at $280{ }^{\circ} \mathrm{C}$ (column: $28 \mathrm{~m} \times 0.32 \mathrm{~mm}$ i.d. HP-5, column temp. $160^{\circ} \mathrm{C}$ ). LC-MS/IT-TOF was recorded on a LCMS-IT-TOF spectrometer (Shimadzu, Kyoto, Japan). Semi-preparative HPLC was performed on an Agilent 1200 apparatus equipped with a UV detector and a Zorbax SB-C-18 $(9.4 \times 250 \mathrm{~mm})$ column (Agilent). Column chromatography (CC) was performed using Sephadex LH-20 (25-100 $\mu \mathrm{m}$; GE Healthcare Bio-Science AB, Uppsala, Sweden), MCI gel CHP 20P (75-150 $\mu \mathrm{m}$; Mitsubishi Chemical, Tokyo, Japan), Diaion HP20SS (Mitsubishi Chemical), Chromatorex ODS (100-200 mesh; Fuji Silysia Chemical, Aichi, Japan), and Toyopearl Butyl-650C (TOSOH, Tokyo, Japan) columns. TLC was performed on precoated Kieselgel $60 \mathrm{~F}_{254}$ plates $(0.2 \mathrm{~mm}$ thick; Merck, Darmstadt, Germany) with toluene- $-\mathrm{HCO}_{2} \mathrm{Et}-\mathrm{HCO}_{2} \mathrm{H}(1: 7: 1, v / v)$ as the solvent, and spots were detected by spraying with a $2 \%$ ethanolic $\mathrm{FeCl}_{3}$.

\subsection{Extraction and Separation}

The fresh leaves of $C$. fargesii $(5.20 \mathrm{~kg})$ were cut into small pieces and extracted three times with $\mathrm{EtOH} / \mathrm{H}_{2} \mathrm{O}(8: 2, v / v, 36 \mathrm{~L})$ by maceration at room temperature for 7 days. The extracts were combined and concentrated under reduced pressure to give an aqueous solution. The solution was partitioned with $\mathrm{Et}_{2} \mathrm{O}$ four times to give the $\mathrm{Et}_{2} \mathrm{O}$ fraction (32.4 g). The aqueous layer was subjected to Sephadex LH-20 CC $(8 \mathrm{~cm}$ i.d. $\times 40 \mathrm{~cm})$ with $0 \%-100 \% \mathrm{MeOH}-\mathrm{H}_{2} \mathrm{O}(20 \%$ stepwise elution, each $1.5 \mathrm{~L})$ to give 9 fractions: frs 1 (15.6 g), 2 (84.5 g), 3 (26.6 g), 4 (27.0 g), 5 (130.0 g), 6 (12.9 g), 7 (3.3 g), 8 (2.3 g), 
and 9 (2.2 g). Fraction fr. $2(84.5 \mathrm{~g})$ was separated by MCI gel CHP 20PCC $(6 \mathrm{~cm}$ i.d. $\times 40 \mathrm{~cm})$ with $\mathrm{MeOH}-\mathrm{H}_{2} \mathrm{O}(10 \%$ stepwise elution, each $1.0 \mathrm{~L})$ to yield seven fractions, and fraction fr. 2-2 $(5.3 \mathrm{~g})$ was further fractionated by Diaion HP20SS CC $(4 \mathrm{~cm}$ i.d. $\times 30 \mathrm{~cm})$ with $\mathrm{H}_{2} \mathrm{O}$ containing increasing proportions of $\mathrm{MeOH}(0 \%-100 \%, 10 \%$ stepwise elution, each $0.5 \mathrm{~L})$ to give $4(105 \mathrm{mg})$. The $\mathrm{Et}_{2} \mathrm{O}$ fraction was subjected to MCI gel CHP 20PCC $(5 \mathrm{~cm}$ i.d. $\times 50 \mathrm{~cm})$ with $0 \%-100 \% \mathrm{MeOH}$ in $\mathrm{H}_{2} \mathrm{O}(10 \%$ stepwise elution, each 0.5 L) to yield 10 fractions: frs E-1 (5.3 g), 2 (7.5 g), $3(1.6 \mathrm{~g}), 4(3.2 \mathrm{~g}), 5(4.3 \mathrm{~g})$, $6(1.5 \mathrm{~g}), 7(2.3 \mathrm{~g}), 8(1.0 \mathrm{~g}), 9(9.9 \mathrm{~g})$ and $10(3.5 \mathrm{~g})$. Fr. E-3 was fractionated by Toyopearl Butyl-650C $\mathrm{CC}(3 \mathrm{~cm}$ i.d. $\times 30 \mathrm{~cm})$ with $0 \%-100 \% \mathrm{MeOH}-\mathrm{H}_{2} \mathrm{O}$ containing $0.1 \% \mathrm{CF}_{3} \mathrm{CO}_{2} \mathrm{H}$ (TFA) $(10 \%$ stepwise elution, each $0.3 \mathrm{~L})$ to give fr. E-31 $(1.3 \mathrm{~g})$ and fr. E-32 $(122 \mathrm{mg})$. Fr. E-32 was further purified by Chromatorex ODS CC $(3 \mathrm{~cm}$ i.d. $\times 30 \mathrm{~cm})$ with $0 \%-80 \% \mathrm{MeOH}$ in $\mathrm{H}_{2} \mathrm{O}(5 \%$ stepwise elution, each $0.2 \mathrm{~L}$ ) to give $3(12 \mathrm{mg})$. Fraction E-4 was separated by Sephadex LH-20 CC $(4 \mathrm{~cm}$ i.d. $\times 40 \mathrm{~cm})$ with $\mathrm{H}_{2} \mathrm{O}$ containing increasing amounts of $\mathrm{MeOH}(0 \%-100 \%, 10 \%$ stepwise elution, each $0.5 \mathrm{~L})$ to yield Fr. E-41 (250 mg), Fr. E-42 (150 mg), Fr. E-43 (296 mg) and Fr. E-44 (1.7 g). The Fr. E-42 and Fr. E-43 were further purified by semi-preparative $\mathrm{HPLC}\left(\mathrm{MeCN} / \mathrm{H}_{2} \mathrm{O}, 20: 80,2.5 \mathrm{~mL} / \mathrm{min}\right.$ ) to give $\mathbf{1}(46 \mathrm{mg}$, $\left.t_{\mathrm{R}} 14.5 \mathrm{~min}\right)$ and $2\left(68 \mathrm{mg}, t_{\mathrm{R}} 13.2 \mathrm{~min}\right)$, respectively.

\subsection{Spectroscopic Data}

(3R,1'S)-[1'-(6"-O-Galloyl- $\beta$-D-glucopyranosyl)oxyethyl]-3-hydroxy-dihydrofuran-2(3H)-one (1): Brown amorphous powder; $[\alpha]_{D}^{25}+52.1^{\circ}(c=0.12, \mathrm{MeOH}) ; \mathrm{UV}(\mathrm{MeOH}) \lambda_{\max } \mathrm{nm}(\log \varepsilon): 272$ (4.32); $\mathrm{CD}(\mathrm{MeOH}) \lambda_{\max }(\Delta \varepsilon) 278$ (8.4), 254 (4.5), 209 (2.7). ${ }^{1} \mathrm{H}$ - and ${ }^{13} \mathrm{C}-\mathrm{NMR}$ data, see Table 1; LC-MS/IT-TOF $m / z[\mathrm{M}-\mathrm{H}]^{-} 459.1143$ (calcd. for $\mathrm{C}_{19} \mathrm{H}_{23} \mathrm{O}_{13}, 459.1144$ ) and $[\mathrm{M}+\mathrm{Na}]^{+} 483.1118$ (calcd. for $\mathrm{C}_{19} \mathrm{H}_{24} \mathrm{O}_{13} \mathrm{Na}$, 483.1109).

(3R,1'S)-3-Hydroxy-1'-hydroxyethyl-dihydrofuran-2(3H)-one (Hydrochloride of 1): $[\alpha]_{D}^{25}-17.0^{\circ}(c=0.15$, $\mathrm{MeOH}) ; \mathrm{UV}(\mathrm{MeOH}) \lambda_{\max } \mathrm{nm}(\log \varepsilon): 265$ (3.16); CD (MeOH) $\lambda_{\max }(\Delta \varepsilon) 267$ (5.7), 251 (3.2), 211 (1.2). ${ }^{1} \mathrm{H}-\mathrm{NMR}\left(\mathrm{MeOH}-d_{4}, 500 \mathrm{MHz}\right) \delta 4.36(1 \mathrm{H}, \mathrm{m}, \mathrm{H}-5 \mathrm{a}), 4.25$ (1H, m, H-5b), 2.11 (1H, m, H-4a), 2.33 $(1 \mathrm{H}, \mathrm{m}, \mathrm{H}-4 \mathrm{~b}), 1.21(3 \mathrm{H}, \mathrm{d}, J=6.5 \mathrm{~Hz}, \mathrm{H}-4), 4.12\left(1 \mathrm{H}, \mathrm{q}, J=6.5 \mathrm{~Hz}, \mathrm{H}-1^{\prime}\right), 1.21\left(3 \mathrm{H}, \mathrm{d}, J=6.5 \mathrm{~Hz}, \mathrm{H}-2^{\prime}\right)$; LC-MS/IT-TOF $m / z 169.0475[\mathrm{M}+\mathrm{Na}]^{+}$(calcd. for $\mathrm{C}_{6} \mathrm{H}_{10} \mathrm{O}_{4} \mathrm{Na}$, 169.0477).

(2R,3S)-2-[2'-(Galloyl)oxyethyl]-dihydroxybutanoic acid (2): Yellow amorphous powder; $[\alpha]_{D}^{25}-16.7^{\circ}$ $(c=0.12, \mathrm{MeOH}) ; \mathrm{UV}(\mathrm{MeOH}) \lambda_{\max } \mathrm{nm}(\log \varepsilon): 267$ (4.26); $\mathrm{CD}(\mathrm{MeOH}) \lambda_{\max }(\Delta \varepsilon) 268$ (10.6), 252 (4.6), 212 (1.4). ${ }^{1} \mathrm{H}$ - and ${ }^{13} \mathrm{C}-\mathrm{NMR}$ data, see Table 1; LC-MS/IT-TOF $m / z 339.0672[\mathrm{M}+\mathrm{Na}]^{+}$(calcd. for $\left.\mathrm{C}_{13} \mathrm{H}_{16} \mathrm{O}_{9} \mathrm{Na}, 339.0687\right)$.

(3S,4S)-3-Hydroxymethyl-3,4-dihydro-5,6,7-trihydroxy-4-(4'-hydroxy-3'-methoxyphenyl)-1H-[2]-benzopyran1-one (3): Brown amorphous powder; $[\alpha]_{D}^{25}+18.3^{\circ}(c=0.11, \mathrm{MeOH})$; UV $(\mathrm{MeOH}) \lambda_{\max } \mathrm{nm}(\log \varepsilon)$ : 220 (4.26), 278 (2.35); $\mathrm{CD}(\mathrm{MeOH}) \lambda_{\max }(\Delta \varepsilon) 288$ (11.4), 242 (6.5), $218(2.7) .{ }^{1} \mathrm{H}-$ and ${ }^{13} \mathrm{C}-\mathrm{NMR}$ data, see Table 2; LC-MS/IT-TOF $m / z 347.0768[\mathrm{M}-\mathrm{H}]^{-}$(calcd. for $\mathrm{C}_{17} \mathrm{H}_{15} \mathrm{O}_{8}, 347.0772$ ).

\subsection{Preparation of MTPA Esters Derivatives}

$\mathrm{CH}_{3} \mathrm{I}(30 \mathrm{mg})$ and $\mathrm{K}_{2} \mathrm{CO}_{3}(15 \mathrm{mg})$ were added to a solution of $2(10 \mathrm{mg})$ in DMF $(5 \mathrm{~mL})$. After stirring for $24 \mathrm{~h}$ at room temperature (r.t.), the reaction mixture was suspended in $\mathrm{H}_{2} \mathrm{O}$ and extracted with $\mathrm{CHCl}_{3}$. The $\mathrm{CHCl}_{3}$ layer was vacuum dried to afford a residue (6.2 $\left.\mathrm{mg}\right)$. Then, DMAP $(3.8 \mathrm{mg}), \mathrm{Et}_{3} \mathrm{~N}(4.0 \mu \mathrm{L})$, and $(R)-(-)-\mathrm{MTPACl}(3.0 \mu \mathrm{L})$ were added to a solution of the residue $(3.1 \mathrm{mg})$ in $\mathrm{CH}_{2} \mathrm{Cl}_{2}(1.0 \mathrm{~mL})$ and stirred for $4 \mathrm{~h}$ at r.t. The reaction mixture was dried under a stream of $\mathrm{N}_{2}$. Separation of the residue was done by a silica gel column (hexane/EtOAc, 4:1) to afford the (S)-MTPA ester derivative $(2.1 \mathrm{mg})$. The $(R)$-MTPA ester derivative $(2.3 \mathrm{mg})$ was obtained according to the same procedure using $(S)-(+)$ MTPACl.

(3S)-MTPA Ester derivative of 2: Colorless oil; ${ }^{1} \mathrm{H}-\mathrm{NMR}\left(\mathrm{MeOH}-d_{4}, 500 \mathrm{MHz}\right) \delta 7.0512-7.3901(7 \mathrm{H})$, $4.8212(1 \mathrm{H}, \mathrm{q}, J=6.6 \mathrm{~Hz}, \mathrm{H}-3), 1.3648(3 \mathrm{H}, \mathrm{d}, J=6.6 \mathrm{~Hz}, \mathrm{H}-4), 2.2511\left(1 \mathrm{H}, \mathrm{m}, \mathrm{H}-1^{\prime} \mathrm{a}\right), 2.3004(1 \mathrm{H}, \mathrm{m}$, 
H-1'b), $4.2526\left(1 \mathrm{H}, \mathrm{m}, \mathrm{H}-2^{\prime} \mathrm{a}\right), 4.2812\left(1 \mathrm{H}, \mathrm{m}, \mathrm{H}-2^{\prime} \mathrm{b}\right), 3.3206-3.8516\left(-\mathrm{OCH}_{3} \times 5\right)$. LC-MS/IT-TOF $m / z$ 611.17147 [M + Na] ${ }^{+}$(calcd. for $\mathrm{C}_{27} \mathrm{H}_{31} \mathrm{~F}_{3} \mathrm{O}_{11} \mathrm{Na}, 611.17162$ ).

(3R)-MTPA Ester derivative of 2: Colorless oil; ${ }^{1} \mathrm{H}-\mathrm{NMR}\left(\mathrm{MeOH}-d_{4}, 500 \mathrm{MHz}\right) \delta 7.0510-7.3902(7 \mathrm{H})$, $4.8210(1 \mathrm{H}, \mathrm{q}, J=6.6 \mathrm{~Hz}, \mathrm{H}-3), 1.3603(3 \mathrm{H}, \mathrm{d}, J=6.6 \mathrm{~Hz}, \mathrm{H}-4), 2.2572\left(1 \mathrm{H}, \mathrm{m}, \mathrm{H}-1^{\prime} \mathrm{a}\right), 2.3088(1 \mathrm{H}, \mathrm{m}$, H-1'b), 4.2548 (1H, m, H-2'a), 4.2858 (1H, m, H-2'b), 3.3312-3.8716 (-OCH $\times$ 5). LC-MS/IT-TOF $m / z$ 611.1710 [M + Na $]^{+}$(calcd. for $\mathrm{C}_{27} \mathrm{H}_{31} \mathrm{~F}_{3} \mathrm{O}_{11} \mathrm{Na}, 611.1716$ ).

\subsection{Preparation of Acetonide Derivative of $\mathbf{2}$}

Compound $2(10.2 \mathrm{mg})$ was dissolved in acetone $(1.0 \mathrm{~mL})$ and treated with DMP $(0.2 \mathrm{~mL})$ and PPTS $(6.5 \mathrm{mg})$ at r.t. After $4 \mathrm{~h}, \mathrm{Et}_{3} \mathrm{~N}(7.5 \mu \mathrm{L})$ was added and the mixture was concentrated by $\mathrm{N}_{2}$ blowing. The residue was separated on a silica gel column $\left(\mathrm{CH}_{2} \mathrm{Cl}_{2} / \mathrm{EtOAc}, 4: 1-2: 1\right)$ to afford the 2,3-O-isopropylidene derivative ( $3.2 \mathrm{mg}$ ) of $\mathbf{2}$.

2,3-O-Isopropylidene Derivative of 2: Colorless oil; ${ }^{1} \mathrm{H}-\mathrm{NMR}\left(\mathrm{MeOH}-d_{4}, 500 \mathrm{MHz}\right) \delta 6.98(2 \mathrm{H}, \mathrm{s}), 4.36$ $(1 \mathrm{H}, \mathrm{q}, J=6.5 \mathrm{~Hz}, \mathrm{H}-3), 1.21(3 \mathrm{H}, \mathrm{d}, J=6.5 \mathrm{~Hz}, \mathrm{H}-4), 2.11\left(1 \mathrm{H}, \mathrm{m}, \mathrm{H}-1^{\prime} \mathrm{a}\right), 2.23\left(1 \mathrm{H}, \mathrm{m}, \mathrm{H}-\mathrm{1}^{\prime} \mathrm{b}\right), 4.25(1 \mathrm{H}, \mathrm{m}$, $\left.\mathrm{H}-2^{\prime} \mathrm{a}\right), 4.29\left(1 \mathrm{H}, \mathrm{m}, \mathrm{H}-2^{\prime} \mathrm{b}\right), 1.27\left(3 \mathrm{H}, \mathrm{s}\right.$, acetonide- $\left.\mathrm{CH}_{3}\right), 1.31\left(3 \mathrm{H}, \mathrm{s}\right.$, acetonide- $\left.\mathrm{CH}_{3}\right)$; LC-MS/IT-TOF $m / z 379.1007[\mathrm{M}+\mathrm{Na}]^{+}$(calcd. for $\mathrm{C}_{18} \mathrm{H}_{20} \mathrm{O}_{9} \mathrm{Na}, 379.1005$ ).

\subsection{Acid Hydrolysis and Sugar Analysis by GC}

Compound $1(6 \mathrm{mg})$ was dissolved in $\mathrm{MeOH}(4.0 \mathrm{~mL})$ and $1 \mathrm{M} \mathrm{H}_{2} \mathrm{SO}_{4}(2.0 \mathrm{~mL})$ and refluxed for $2 \mathrm{~h}$ on a $\mathrm{H}_{2} \mathrm{O}$ bath. After the hydrolysate was cool, $\mathrm{H}_{2} \mathrm{O}(8.0 \mathrm{~mL})$ was added, then extracted with EtOAc $(3 \times 10.0 \mathrm{~mL})$. The EtOAc layer was vacuum dried and chromatographed on semi-preparative HPLC eluting with a gradient of $\mathrm{MeOH}-\mathrm{H}_{2} \mathrm{O}(5: 95-25: 75, v / v)$ to afford 3-hydroxy-1'-hydrooxyethyl-dihydrofuran-2(3H)-one. The aqueous layer was neutralized with aqueous $\mathrm{Ba}(\mathrm{OH})_{2}$ and evaporated under reduced pressure to give a residue. The residue was dissolved in pyridine $(100 \mu \mathrm{L})$, subsequent treated with $0.1 \mathrm{~mL}$ cysteine methyl ester hydrochloride $(150 \mu \mathrm{L}$; Sigma, St. Louis, MO, USA) and warmed at $60{ }^{\circ} \mathrm{C}$ for $1 \mathrm{~h}$, then the trimethysilylation reagent HMDS/TMCS (hexamethyldisilazane/trimethylchlorosilane/pyridine 2:1:10; Acros Organics, Geel, Belgium) was added and warmed at $60^{\circ} \mathrm{C}$ for $30 \mathrm{~min}$. The reaction mixture was partitioned between water and hexane. The hexane extract was analyzed by GC [15] (detector temperature: $280^{\circ} \mathrm{C}$; injector temperature: $250{ }^{\circ} \mathrm{C}$; temperature gradient: start at $160{ }^{\circ} \mathrm{C}$, hold for $5 \mathrm{~min}$, increase to $280{ }^{\circ} \mathrm{C}$ at $5{ }^{\circ} \mathrm{C} / \mathrm{min}$, hold for $10 \mathrm{~min}$ ). The authentic samples were analyzed in the same way. The $t_{\mathrm{R}}$ values of D-glucose and L-glucose were $13.25 \mathrm{~min}$ and $15.32 \mathrm{~min}$, respectively. The thiazolidine derivatives of the samples were confirmed by comparison with authentic standards.

\subsection{Cytotoxicity Assay}

All isolates were tested for cytotoxicity in vitro against A549, SMMC-7721, MGC-803, HepG2, and MCF-7 tumour cells via the MTT assay $[16,17]$ with hydroxycamptothecine as a positive control.

\section{Conclusions}

In this study, we separated and identified three new compounds 1-3 and a known compound 4 from the leaves of $C$. fargesii. The 2,3-dihydroxy-2-(2-hydroxyethyl)-butanoic acid moiety in $\mathbf{1}$ and $\mathbf{2}$ is an unusual carboxylic acid in Nature, thus, these compounds might be recognized as chemotaxonomic markers. Our preliminary examination also suggested this plant contains triterpene HHDP esters, which are important chemotaxonomical markers of Castanopsis sp.; therefore, further phytochemical investigations of the leaves of $C$. fargesii are in progress.

Acknowledgments: We gratefully acknowledge support from the Guangxi Natural Science Foundation (2014GXNSFCB118001), National Natural Science Foundation China (21562008), “Western Light" Talent Training Plan of Chinese Academy of Sciences (No. [2013]165), Science Research Foundation of Guangxi Academy of Sciences (15YJ22ZWS22) and Program for Bagui Scholars of Guangxi Institute of Botany (The third batch). 
Author Contributions: In this work, Yong-Lin Huang designed the experiments and the manuscript writing; Ya-Feng Wang, Jin-Lei Liu, Yue-Yuan Chen, and Feng-Lai Lu performed the extraction, isolation; Lei Wang and Dian-Peng Li carried out the structural elucidations; Takashi Tanak are viewed the manuscript.

Conflicts of Interest: The authors declare no conflict of interest.

\section{References}

1. CAS. Flora Republicae Popularis Sinicae; China Science Publishing \& Media Ltd.: Beijing, China, 1998; Volume 13-14, p. 55.

2. Suranto. Application of modern experimental technique to solve morphological complexity in plants taxonomy. Biodiversitas 2000, 10, 80-84.

3. Ageta, M.; Nonaka, G.; Nishioka, I. Tannins and related compounds. LXVII. Isolation and characterization of castanopsinins A-H, novel ellagitannins containing a triterpenoid core, from Castanopsis cuspidata var. sieboldii NAKAI (3). Chem. Pharm. Bull. 1988, 36, 1646-1663. [CrossRef]

4. Chen, H.F.; Tanaka, T.; Nonaka, G.; Fujoka, T.; Mihsahi, K. Hydrolysable tannins based on a triterpenoid glycoside core, from Castanopsis hystrix. Phytochemistry 1993, 32, 1457-1460. [CrossRef]

5. Huang, Y.L.; Tsujita, T.; Tanaka, T.; Matsuo, Y.; Kouno, I.; Li, D.P.; Nonaka, G.I. Triterpene hexahydroxydiphenoyl esters and a quinic acid purpurogallin carbonyl ester from the leaves of Castanopsis fissa. Phytochemistry 2011, 72, 2006-2014. [CrossRef] [PubMed]

6. Huang, Y.L.; Matsuo, Y.; Tanaka, T.; Kouno, I.; Li, D.P.; Nonaka, G.I. New phenylpropanoid-substituted flavan-3-ols from the leaves of Castanopsis sclerophylla. Heterocycles 2011, 83, 2321-2328.

7. Huang, Y.L.; Tanaka, T.; Matsuo, Y.; Kouno, I.; Li, D.P.; Nonaka, G.I. Two new phenolic glucosides and an ellagitannin from the leaves of Castanopsis sclerophylla. Phytochem. Lett. 2012, 5, 158-161. [CrossRef]

8. Huang, Y.L.; Tanaka, T.; Matsuo, Y.; Kouno, I.; Li, D.P.; Nonaka, G.I. Isolation of ellagitannin monomer and macrocyclic dimer from Castanopsis carlesii leaves. Heterocycles 2012, 86, 381-389.

9. Fujii, S.; Aoki, H.; Kômoto, M. Fluorescent glycosides accumulated in Taphrina weisneri-infected Cherry stems. Agric. Biol. Chem. 1971, 35, 1526-1534. [CrossRef]

10. Yoshi, T.; Fenga, W.S.; Okuda, T. Two polyphenol glycosides and tannins from Rosa cymosa. Phytochemistry 1993, 32, 1033-1036. [CrossRef]

11. Ohtani, I.; Kusumi, T.; Kashman, Y.; Kakisawa, H. A new aspect of the high-field NMR application of Mosher's method. The absolute configuration of marine triterpene sipholenol A. J. Am. Chem. Soc. 1991, 113, 4092-4095. [CrossRef]

12. Kusumi, T.; Ooi, T.; Ohkubo, Y.; Yabuuchi, T. The Modified Mosher's Method and the Sulfoximine Method. ChemInform 2006, 37, 965-980. [CrossRef]

13. Duan, W.J.; Jin, X.; Chen, L.X. Four new compounds from Paeonia albiflora. J. Asian Nat. Prod. Res. 2009, 11, 299-305. [CrossRef] [PubMed]

14. Magid, A.A.; Voutquenne-Nazabadioko, L.; Moroy, G.; Moretti, C.; Lavaud, C. Dihydroisocoumarin glucosides from stem bark of Caryocar glabrum. Phytochemistry 2007, 68, 2439-2443. [CrossRef] [PubMed]

15. Chen, Y.Y.; Pan, Q.D.; Li, D.P.; Liu, J. L.; Wen, Y.X.; Huang, Y.L.; Lu, F.L. New pregnane glycosides from Brucea javanica and their antifeedant activity. Chem. Biodivers. 2011, 8, 460-466. [CrossRef] [PubMed]

16. Alley, M.C.; Scudiero, D.A.; Monks, A.; Hursey, M.L.; Czerwinski, M.J.; Fine, D.L.; Abbott, B.J.; Mayo, J.G.; Shoemaker, R.H.; Boyd, M.R. Feasibility of drug screening with panels of human tumor cell lines using a microculture tetrazolium assay. Cancer Res. 1988, 48, 589-601. [PubMed]

17. Ge, Y.Z.; Zhang, H.; Liu, H.C.; Dong, L.; Ding, J.; Yue, J.M. Cytotoxic dinorditer penoids from Drypetes perreticulata. Phytochemistry 2014, 100, 120-125. [CrossRef] [PubMed]

Sample Availability: Samples of the compounds 1-4 are available from the authors.

(C) 2017 by the authors; licensee MDPI, Basel, Switzerland. This article is an open access article distributed under the terms and conditions of the Creative Commons Attribution (CC BY) license (http:/ / creativecommons.org/licenses/by/4.0/). 